\title{
Analysis of the Regression and Correlation of Gross Domestic Product (GDP) Exports and Revenue (GDP) of Indonesia against Rupiah Exchange Rate (IDR - USD)
}

Dodi Irwan Siregar* and Raden Rudi Alhempi

Dosen STIE Persada Bunda Jl, Diponegoro, Indonesia

\begin{abstract}
As explained in the Mundell-Fleming theory, which states that there is a negative influence between exchange rate and economic growth, where the higher the exchange rate, the lower net exports (the difference between exports and imports) will decrease the amount of output decreases and will cause GDP (Economic growth) to decline. This study uses multiple linear regression analysis to predict and predict the change of value of certain variables when other variables change. Correlation is one of the analytical techniques in statistics used to find the relationship between two or more variables that are quantitative. Then obtained multiple linear regression equation between Rupiah Currency Exchange Rate (Y), Export Value of Indonesia (X1) and Indonesia Gross Domestic Product at Current Market Price Based on Business as variable (X2), that is obtained by multiple linear regression equation is $Y=-5050,90239+0,0095804$ $\mathrm{X} 1+0,0014006 \mathrm{X} 2$ where Interpretation of correlation between the relationship of Currency Exchange IDR (Y), Export Value of Indonesia (X1) and Gross Domestic Product at Current Price Based on The field of business (X2) is 0.973 with a very strong interpretation that ranges from 0.75 to 0.99
\end{abstract}

Keywords: IDR-USD rupiah rate; Indonesian export-import value; Indonesian gross domestic product; Indonesian state; Multiple linear regression; Multiple linear correlation

\section{Introduction}

The exchange rate or exchange rate is the amount of domestic money needed, i.e., the amount of rupiah required to acquire 1 unit of foreign currency. As explained in the Mundell-Fleming theory (Mankiw, 2006), which states that there is a negative influence between exchange rate and economic growth, where the higher the exchange rate, the lower net exports (the difference between exports and imports) will decrease the amount of output decreases and will cause GDP (Economic growth) to decline [1]. The exchange rate can be interpreted as the number of units of currency needed to be convertible with per unit of another currency, or in other words, the price of a currency against another currency [2]. Meanwhile, according to the Indonesian bank dictionary, the exchange rate (exchange rate, rate of exchange) is the exchange rate of a country's money unit against other countries.

Gross Domestic Product is defined as the overall value of all goods and services produced within the territory within a certain period of time (usually per year). GDP differs from gross national product by incorporating the income of factors of production from abroad working in that country. So the GDP only calculates the total production of a country regardless of whether the production is made by using domestic factors of production or not. Exports are the process of transporting goods or commodities to a country. To other countries, this process is often used by companies with small to medium business scale as the main strategy to compete in international level. Export strategy is used because of lower risk, smaller capital and easier when compared with other strategies such as franchise and acquisition. This study illustrates certain indicators of Indonesia's macro economy which are an important tool for evaluating the current state of the Indonesian economy. Moreover, statistical analysis can help predict future economic performance.

\section{Literature Review}

\section{Multiple linear regression analysis}

Multiple linear regression analysis is used to predict the change in the value of a particular variable when another variable changes. It is said multiple regression, because the number of independent variables (independent) as a predictor of more than one, then used multiple linear regression equation. Regression analysis is the relationship obtained and expressed in term of mathematical equations that express the functional relationship between the variables.

According to Drapper and Smith (1992) regression analysis is an analytical method that can be used to analyze data and draw meaningful conclusions about the dependence relationship of variables on other variables [3]. Regression is divided into 2 i.e., simple linear regression analysis is used to obtain a mathematical relationship in the form of an equation between the dependent variable with a single independent variable. Multiple linear regression analysis is a linear relationship between two or more independent variables $\left(\mathrm{X} 1, \mathrm{X} 2, \ldots . \mathrm{X}_{\mathrm{n}}\right)$ with the dependent variable $(\mathrm{Y})$. This analysis is to know the direction of relation between independent variable and dependent variable whether each independent variable is positive or negative and to predict the value of the dependent variable if the value of the independent variable increases or decreases. The data used are usually scaled intervals or ratios.

Multiple linear regression equation as follows:

$\mathrm{Y}=\mathrm{a}+\mathrm{b} 1 \mathrm{X} 1+\mathrm{b} 2 \mathrm{X} 2+\ldots \ldots+\mathrm{bnXn}$

Information:

*Corresponding author: Dodi Irwan Siregar, Dosen STIE Persada Bunda JI, Diponegoro, Indonesia, Tel: 0761-23181/081233964593; E-mail: dodi.irwan.siregar@gmail.com

Received October 04, 2018; Accepted November 20, 2018; Published November 27, 2018

Citation: Siregar DI, Alhempi RR (2018) Analysis of the Regression and Correlation of Gross Domestic Product (GDP) Exports and Revenue (GDP) of Indonesia against Rupiah Exchange Rate (IDR - USD). J Glob Econ 6: 320. doi: $10.4172 / 2375-4389.1000320$

Copyright: @ 2018 Siregar DI, et al. This is an open-access article distributed under the terms of the Creative Commons Attribution License, which permits unrestricted use, distribution, and reproduction in any medium, provided the original author and source are credited. 


\section{Y=Dependent variable (predicted value)}

$\mathrm{X} 1$ and $\mathrm{X} 2=$ Independent variables

$\mathrm{a}=$ Constant $(\mathrm{Y}$ value if $\mathrm{X} 1, \mathrm{X} 2 \ldots . . \mathrm{Xn}=0)$

$\mathrm{b}=$ Regression coefficient (value increase or decrease).

The method that can be used to estimate the parameters of simple linear regression model and multiple linear regression model is by smallest ordinary least squares (OLS) method and maximum likelihood estimation (MLE) [4].

\section{Multiple linear correlation}

The correlation coefficient is a number that states the strength of the relationship between two or more variables, can also determine the direction of the relationship of the two variables, the correlation value is $(r)=(-1 \leq 0 \leq 1)$. Multiple correlation analysis is an extension of simple correlation analysis. In multiple correlation analysis aims to find out how the degree of relationship between several independent variables (Variables X1, X2, ......., Xk) with dependent variable (Variable Y) together. For the strength of the relationship, the value of the correlation coefficient is between -1 to 1 , while for the direction is expressed in positive (+) and negative (-). The coefficient of multiple linear

$$
\begin{aligned}
& R_{Y=12}=\sqrt{\frac{r_{Y 1}^{2}+r_{Y 2}^{2}-2 r_{Y 1} r_{Y 2} r_{Y 12}}{1-r_{Y 12}^{2}}} \\
& r_{Y 1}=\frac{n \sum X_{1} Y-\left(\sum Y\right)\left(\sum X_{1}\right)}{\sqrt{\left(n \sum Y^{2}-\left(\sum Y\right)^{2}\right)}\left(n \sum X_{1}^{2}-\left(X_{1}\right)^{2}\right)} \\
& r_{Y 2}=\frac{n \sum X_{2} Y-\left(\sum Y\right)\left(\sum X_{2}\right)}{\sqrt{\left(n \sum Y^{2}-\left(\sum Y\right)^{2}\right)}\left(n \sum X_{2}^{2}-\left(X_{2}\right)^{2}\right)} \\
& r_{12}=\frac{n \sum X_{1} X_{2}-\left(\sum X_{1}\right)\left(\sum X_{2}\right)}{\sqrt{\left(n \sum X_{1}^{2}-\left(\sum X_{1}\right)^{2}\right)}\left(n \sum X_{2}^{2}-\left(X_{2}\right)^{2}\right)}
\end{aligned}
$$

Correlation is calculated by using the following formula:

Where:

Ry12 : Correlation of dependent variable to independent variables 1 and 2 .

ry1: Correlation of dependent variable with independent variable 1.

ry2: Correlation of dependent variable with independent variable 2.

n: Many samples.

$\mathrm{X} 1$ : Independent variable 1.

$\mathrm{X} 2$ : Independent variable 2.

Y: Dependent variable (free).

Based on the multiple correlation, given the notation RY.12 .....n is calculated through the path of occurrence of relationship between several independent variables $(\mathrm{X} 1, \mathrm{X} 2, \ldots \ldots . . . \mathrm{Xn})$ with one dependent variable $(Y)$, i.e., in the form of multiple linear regression $Y^{\prime}=a+b 1$. $\mathrm{X} 1+\mathrm{b} 2 . \mathrm{X} 2+\ldots \ldots+\mathrm{bn} . \mathrm{Xn}$. The strength interval of a number of statistical authors creates a categorization interval of the strength of the correlation relationship [5].

Jonathan Sarwono, for example, makes the interval of the power of relationship as follows (Table 1):

Multiple Correlation is a correlation that intends to see the

\begin{tabular}{|c|c|}
\hline Correlation value (r) & Interpretations $(\mathbf{r})$ \\
\hline $0.00-0.00$ & No correlations \\
\hline $0.00-0.25$ & Very weak \\
\hline $0.25-0.50$ & Medium \\
\hline $0.50-0.75$ & Strong \\
\hline $0.75-0.99$ & Very strong \\
\hline $0.99-1.00$ & Perfect correlations \\
\hline Source: Sugiyono, 2008. & \\
\hline
\end{tabular}

Table 1: Pearson correlation value.

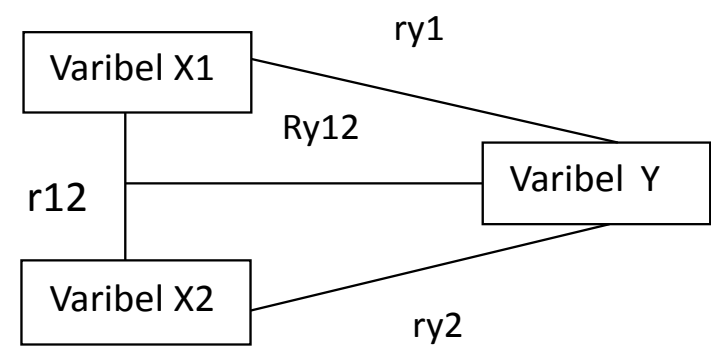

Figure 1: Multiple linear correlation.

relationship between 3 or more variables (two or more dependent variables and one independent variable). Multiple correlations relate to the intercalation of independent variables as their correlation with the dependent variable. In addition, according to for each variable, the value of observations from one another, is not related. Double correlation is a value that gives strong influence or relationship of two or more variables together with other variables [6].

The assumptions regarding the multiple regression analysis are:

1. Independent variables and dependent variables have a linear relationship.

2. All variables, both independent variables and dependent variables, are continuous random variables.

3. The conditional distribution of the value of each variable is normally distributed (multivariate normal distribution).

4. For various combinations of value variables that one with another particular, the variance of the conditional distribution of each variable is homogeneous (assuming homoscedasticity applies to all variables). For each variable, the value of observations from one another, is not related.

Multiple correlations is a correlation consisting of two independent variables $(\mathrm{X} 1, \mathrm{X} 2)$ or more, and one dependent variable $(\mathrm{Y})$. As for the relationship between variables can be described as follows:

From the picture above the formulation of the problem consists of three or more problems, then used multiple linear correlation (Figure 1).

\section{Methods}

\section{Types and research approach}

This research includes Explanatory Research with Quantitative approach, using multiple linear analysis method because the independent variable more than one. The influencing variable is called independent variable (independent variable) and the influenced variable is called dependent variable (dependent variable). 
Citation: Siregar DI, Alhempi RR (2018) Analysis of the Regression and Correlation of Gross Domestic Product (GDP) Exports and Revenue (GDP) of Indonesia against Rupiah Exchange Rate (IDR - USD). J Glob Econ 6: 320. doi: 10.4172/2375-4389.1000320

Page 3 of 5

\section{Variable in measurement}

This study consists of two independent variables, namely the value of Indonesian Exports to Foreign Countries (X1) and Indonesian Gross Domestic Product (X2), while the dependent variable is the Rupiah Currency Rate (IDR - USD) abbreviated as Variable (Y).

\section{Data source}

Sources of data used are secondary data sources that are data sources of research obtained indirectly through media intermediaries or agencies/agencies concerned [7]. In this case the researchers take data from the Central Bureau of Statistics 2017 on Export Value, Gross Domestic Revenue (GDP) and Rupiah Currency Exchange Rate (IDR USD) at BPS Indonesia 2017.

\section{Data collection technique}

The data collection technique used to obtain relevant data from the problems studied is through literature study (Library Research), that is by reading and studying the literature contained in the library, with the intention to place the theoretical foundation on the subject matter being discussed (Table 2).

The exchange rate (otherwise known as the exchange rate) is an agreement known as the exchange rate of a currency against current or future payments, between two currencies of each country or region. The value of Indonesian exports from year to year according to statistical data tend to decrease, it can be seen in the following statistics table (Table 3).

Gross Domestic Product is defined as the overall value of all goods and services produced within the territory within a certain period of time (usually per year) (Table 4).

\section{Result and Discussion}

This study predicts and foresaw the future position of rupiah exchange rate (IDR - USD) by processing and analyzing data in the past, as dependent variable, is the total of Indonesia's overall Overseas Debt and Gross Domestic Revenue as independent variable by predicting these variables use multiple linear regression equations. The data can be seen as follows (Table 5).

Multiple linear regression analysis with dependent variable is the exchange rate of Rupiah (IDR-USD) abbreviated with (Y), and independent variable is Indonesian Export Value (X1), and Indonesian Gross Domestic Product (X2). Data from the above variables are as follows (Table 6):

\begin{tabular}{|c|c|c|c|c|c|}
\hline Description & 2011 & 2012 & 2013 & 2014 & 2015 \\
\hline 1 & 2 & 3 & 4 & 5 & 6 \\
\hline United States dollar & 9.068 & 9.670 & 12.189 & 12.440 & 13.795 \\
\hline Euro & 11.739 & 12.810 & 16.821 & 15.133 & 15.070 \\
\hline Pound sterling inggris & 13.969 & 15.579 & 20.097 & 19.370 & 20.451 \\
\hline Dollar Singapore & 6.974 & 7.907 & 9.628 & 9.422 & 9.751 \\
\hline Dollar Australia & 9.203 & 10.025 & 10.876 & 10.218 & 10.064 \\
\hline Yen Japan & 117 & 112 & 116 & 104 & 114 \\
\hline Ringgit Malaysia & 2.853 & 3.160 & 3.708 & 3.562 & 3.210 \\
\hline Dollar Hongkong & 1.167 & 1.247 & 1.572 & 1.604 & 1.780 \\
\hline Emas/gold & 450.000 & 460.000 & 470.000 & 478.402 & 495.752 \\
\hline
\end{tabular}

Table 2: Exchange rate data of rupiah currency and gold price in Jakarta (rupiah) 2011-2016.

\begin{tabular}{|c|c|c|c|c|c|c|}
\hline \multirow[t]{2}{*}{ Year } & \multicolumn{2}{|c|}{ Non-oil and gas } & \multicolumn{2}{|c|}{ Oil and gas } & \multicolumn{2}{|c|}{ Total } \\
\hline & Export & Import & Export & Import & Export & Import \\
\hline 2011 & $162.019,6$ & $136.734,1$ & $41.477,0$ & $40.701,5$ & $203.496,6$ & $177.435,6$ \\
\hline 2012 & $153.043,0$ & $149.125,3$ & $36.977,3$ & $42.564,2$ & $190.020,3$ & $191.689,5$ \\
\hline 2013 & $149.918,8$ & $141.362,3$ & $32.633,0$ & 45.266 & $182.551,8$ & $186.628,7$ \\
\hline 2014 & $145.961,2$ & $134.718,9$ & $30.018,8$ & $43.459,9$ & $175.980,0$ & $178.178,8$ \\
\hline 2015 & $131.791,9$ & $118.081,6$ & $18.574,4$ & $24.613,2$ & $150.366,3$ & $142.694,8$ \\
\hline 2016 & $132.080,8$ & $116.913,0$ & $13.105,5$ & $18.739,8$ & $145.186,2$ & $135.652,8$ \\
\hline
\end{tabular}

Table 3: Export value table1 and import 2 Indonesia (million US \$), from 2011-2016.

\begin{tabular}{|c|c|c|c|c|}
\hline Business field & $\mathbf{2 0 1 2}$ & $\mathbf{2 0 1 3}$ & $\mathbf{2 0 1 4}$ \\
\hline 1 & 2 & 3 & $\mathbf{2 0 1 5}$ \\
\hline A. Gross domestic product & $8.615 .704,5$ & $9.546 .134,0$ & $10.569 .705,3$ & $11.531 .716,9$ \\
\hline B. Gross added value for basic prices & $8.429 .699,5$ & $10.306 .232,4$ & $10.306 .232,4$ & $11.169 .265,1$ \\
\hline C. Tax deducted by subsidies on products & $186.005,0$ & $237.802,4$ & $263.472,9$ & $362.451,8$ \\
\hline
\end{tabular}

Source: BPS Indonesia 2017.

Table 4: Gross domestic product at current market prices by industrial origin (billion rupiah) in 2012-2016.

\begin{tabular}{|c|c|c|c|c|}
\hline Description & $\mathbf{2 0 1 1}$ & $\mathbf{2 0 1 2}$ & $\mathbf{2 0 1 3}$ & $\mathbf{2 0 1 5}$ \\
\hline 1 & 2 & 3 & 4 & 5 \\
\hline US dollar & 9.068 & 9.670 & 12.189 & 12.440 \\
\hline
\end{tabular}

Table 5: Data dependent variable (free) exchange rate of rupiah against US dollar from year 2011-2016. 
Citation: Siregar DI, Alhempi RR (2018) Analysis of the Regression and Correlation of Gross Domestic Product (GDP) Exports and Revenue (GDP) of Indonesia against Rupiah Exchange Rate (IDR - USD). J Glob Econ 6: 320. doi: 10.4172/2375-4389.1000320

Page 4 of 5

In a study during the data analysis phase, multiple linear regression is the development of simple linear regression, which can be used to predict future demand based on data analysis in the past or to determine the effect of one or more independent variables on a single variable free (dependent) used. The application of multiple methods the number of independent variables used more than one that affect independent independent variables [8].

From the free variable data table and bound above the obtained multiple linear regression equation with two predictors. Get started by creating a helper table as follows (Table 7):

\section{Look for the value of constants a}

a. The constants $b 1$ and $b 2$ are:

- $\Sigma \mathrm{x}_{1}^{2}=\mathrm{X}_{1}^{2}-\left(\Sigma \mathrm{X}_{1}\right)^{2} / \mathrm{n}$

- $\quad \Sigma \mathrm{x}_{2}{ }^{2}=\Sigma \mathrm{X}_{2}{ }^{2}-\left(\Sigma \mathrm{X}_{2}\right)^{2} / \mathrm{n}$

- $\quad \Sigma \mathrm{y}^{2}=\sum \mathrm{Y}^{2}-(\Sigma \mathrm{Y})^{2} / \mathrm{n}$

- $\quad \Sigma \mathrm{x}_{1} \mathrm{y}^{\mathrm{y}} \Sigma \mathrm{X}_{1} \mathrm{Y}-\left(\Sigma \mathrm{X}_{1}\right)(\Sigma \mathrm{Y}) / \mathrm{n}$

- $\quad \sum \mathrm{x}_{2} \mathrm{y}^{=} \Sigma \mathrm{X}_{2} \mathrm{Y}-\left(\Sigma \mathrm{X}_{2}\right)(\Sigma \mathrm{Y}) / \mathrm{n}$

- $\quad \Sigma \mathrm{x}_{1} \mathrm{X}_{2}=\Sigma \mathrm{X}_{1} \mathrm{X}_{2}-\left(\Sigma \mathrm{X}_{1}\right)\left(\Sigma \mathrm{X}_{2}\right) / \mathrm{n}$

$\bar{X}_{1}=\Sigma X_{1} / n$

$\bar{X}_{2}=\Sigma X_{2} / n$

$\overline{\mathrm{Y}}=\Sigma Y / n$.

The formula of the constant bl;

$\mathrm{b} 1=\frac{\left(\sum x_{2} 2\right)\left(\sum x_{1} y\right)-\left(\sum x_{1} x_{2}\right)\left(\sum x_{2} y\right)}{\left(\sum x_{1} 2\right)\left(\sum x_{2} 2\right)-\left(\sum x_{1} x_{2}\right)^{2}}$

$=0,0095804$

The formula of the constant $b 2$;

$$
b 2=\frac{\left(\sum x_{1} 2\right)\left(\sum x_{2} y\right)-\left(\sum x_{1} x_{2}\right)\left(\sum x_{1} y\right)}{\left(\sum x_{1} 2\right)\left(\sum x_{2} 2\right)-\left(\sum x_{1} x_{2}\right)^{2}}
$$

$=0,0014006$

b. The value of the constant $\alpha$ is:

$$
\begin{aligned}
& \alpha=\sum Y / n-b 1\left(\sum X 1 / n\right)-b 2\left(\sum X 2 / n\right) \\
& =-5050,9039
\end{aligned}
$$

From the results of multiple linear regression analysis obtained equation with the formula is as follows:

\section{$\mathrm{Y}=\mathrm{a}+\mathrm{b} 1 \mathrm{X} 1=\mathrm{b} 2 \mathrm{X} 2$}

The results of multiple linear regression analysis obtained by the equation of Currency Exchange IDR-USD (Y), Export Value Indonesia (X1) and Gross Domestic Product (X2) then obtained the following results:

$\mathrm{Y}=-5050,90239+0,0095804 \mathrm{X} 1+0,0014006 \mathrm{X} 2$.

By using the above equation we can predict the value of the rupiah exchange rate using the equation (Table 8).

\section{Level of multiple linear regression correlation}

The Pearson Correlation Coefficient can be used to express the linear relationship between two or more variables when data is quantitative data (interval or ratio data) and both variables are normal distributed bivariates. Then obtained the correlation of multiple linear regression are as follows (Table 9):

$$
\begin{aligned}
\mathrm{R}_{\mathrm{Y} .12} & =\sqrt{ } \mathrm{r}^{2} \mathrm{y} 1+\mathrm{r} 2 \mathrm{y} 2-2 \mathrm{ry} 1 . \mathrm{ry} 2 . \mathrm{ry} 12 / \sqrt{ } 1-\mathrm{r} 2 \mathrm{y} 12 \\
& =0,973684611 .
\end{aligned}
$$

From the analysis of multiple linear regression linear regression equation of IDR-USD Currency Exchange Rate (Y), Export Value of Indonesia (X1) and Gross Domestic Product (X2), the result is 0.973 with interpretation is very strong that is between 0.75 and 0.99 .

\begin{tabular}{|c|c|c|c|c|}
\hline Indonesia's export value & $\mathbf{2 0 1 1}$ & $\mathbf{2 0 1 2}$ & $\mathbf{2 0 1 3}$ & $\mathbf{2 0 1 5}$ \\
\hline 1 & 2 & 3 & 4 & 5 \\
\hline Total & $203.496,6$ & $190.020,3$ & $182.551,8$ & $175.980,0$ \\
\hline
\end{tabular}

Table 6: Export value 1 and import 2 Indonesia (million US \$), from 2011 to 2016.

\begin{tabular}{|c|c|c|c|c|c|c|c|c|c|}
\hline Year & $\mathbf{Y}$ & $\mathrm{X} 1$ & $\mathrm{X} 2$ & $X 1^{2}$ & $X 2^{2}$ & $\mathbf{Y}^{2}$ & $\mathrm{X} 1 \mathrm{Y}$ & $\mathrm{X} 2 \mathrm{Y}$ & $\mathrm{X} 1 \mathrm{X} 2$ \\
\hline 2011 & 9.068 & $203.496,6$ & $8.615 .704,5$ & $5,08 \times 10^{10}$ & $7,42 \times 10^{13}$ & $0,82 \times 10^{7}$ & $2,04 \times 10^{9}$ & $0,78 \times 10^{11}$ & $1,94 \times 10^{12}$ \\
\hline 2012 & 9.670 & $190.020,3$ & $9.546 .134,0$ & $6,37 \times 10^{10}$ & $9,11 \times 10^{13}$ & $0,94 \times 10^{7}$ & $2,44 \times 10^{9}$ & $0,92 \times 10^{11}$ & $2,41 \times 10^{12}$ \\
\hline 2013 & 12.189 & $182.551,8$ & $10.569 .705,3$ & $7,08 \times 10^{10}$ & $11,17 \times 10^{13}$ & $1,5 \times 10^{8}$ & $3,24 \times 10^{9}$ & $1,29 \times 10^{11}$ & $2,81 \times 10^{12}$ \\
\hline 2014 & 12.440 & $175.980,0$ & $11.531 .716,9$ & $8,63 \times 10^{10}$ & $13,29 \times 10^{13}$ & $1,5 \times 10^{8}$ & $3,65 \times 10^{9}$ & $1,43 \times 10^{11}$ & $3,38 \times 10^{12}$ \\
\hline 2015 & 13.795 & $150.366,3$ & $12.406 .809,8$ & $9,10 \times 10^{10}$ & $15,39 \times 10^{13}$ & $1,9 \times 10^{10}$ & $4,16 \times 10^{9}$ & $1,71 \times 10^{11}$ & $3,74 \times 10^{12}$ \\
\hline$\Sigma$ & 57.162 & 1.339 .340 & 52.670 .071 & $36,26 \times 10^{10}$ & $56,39 \times 10^{13}$ & $6,7 \times 10^{8}$ & $15,5 \times 10^{9}$ & $6,14 \times 10^{11}$ & $1,42 \times 10^{13}$ \\
\hline
\end{tabular}

\begin{tabular}{|c|c|c|c|c|}
\hline Business field & $\mathbf{2 0 1 2}$ & $\mathbf{2 0 1 3}$ & $\mathbf{2 0 1 4}$ & $\mathbf{2 0 1 6}$ \\
\hline 1 & 2 & 3 & 4 & 5 \\
\hline C. Gross domestic product & $8.615 .704,5$ & $9.546 .134,0$ & $10.569 .705,3$ & $11.531 .716,9$ \\
\hline
\end{tabular}

Table 7: Data of gross domestic product at current prices by business field (milliar rupiah) in 2012-2016.

\begin{tabular}{|c|c|c|c|}
\hline No. & United states dollar (Y) & Indonesian exports (X1) / million US \$ & Gross domestic product (X2) / billion rupiah \\
\hline 1 & 9.068 & $203.496,6$ & $8.615 .704,5$ \\
\hline 2 & 9.670 & $190.020,3$ & $9.546 .134,0$ \\
\hline 3 & 12.189 & $182.551,8$ & $10.569 .705,3$ \\
\hline 4 & 12.440 & $175.980,0$ & $11.531 .716,9$ \\
\hline 5 & 13.795 & $150.366,3$ & $12.406 .809,8$ \\
\hline
\end{tabular}

Table 8: Currency exchange rate USD-USD (Y), export value of Indonesia (X1) and product gross domestic (X2).

Table 9: Helper data to find multiple linear regression equation is constant value $b 1$ and $b 2$. 
Citation: Siregar DI, Alhempi RR (2018) Analysis of the Regression and Correlation of Gross Domestic Product (GDP) Exports and Revenue (GDP) of Indonesia against Rupiah Exchange Rate (IDR - USD). J Glob Econ 6: 320. doi: 10.4172/2375-4389.1000320

Page 5 of 5

\section{Conclusion}

From the results of this study it can be concluded that multiple linear regression analysis is used in analysing Currency Rate IDRUSD (Y), Export Value Indonesia (X1) and Gross Domestic Product (X2) obtained Multiple linear regression equation is as follows: $\mathrm{Y}=-$ $5050,90239+0,0095804 \mathrm{X} 1+0,0014006 \mathrm{X} 2$ where Interpretation of the correlation between the relationship of Currency Exchange IDR (Y), Export Value Indonesia (X1) and Gross Domestic Product (X2) so that the result is 0,973 with interpretation is very strong that is ranged from 0.75 to 0.99 .

\section{References}

1. Mankiw G (2006) Introduction to Macro Economics ( $3^{\text {rd }}$ edn.), Salemba Empat Jakarta.
2. Samuelson PA, Nordhaus WD (2004) Macroeconomics. Indonesian Edition, Jakarta: PT Media Global Education.

3. Draper NH, Smith (1992) Analysis of Applied Regression. (2 ${ }^{\text {nd }}$ edn.), Translation by Bambang Sumantri. Gramedia Main Library, Jakarta.

4. Kutner MH, Nachtsheim CJ, dan JN (2004) Applied Linear Regression Models ( $4^{\text {th }}$ edn.), McGraw-Hill Companies Inc, New York.

5. Sugiyono (2006) Statistics for Research, Mold Seventh. Bandung: CV. Alfabeta

6. Akdon DR (2013) Formulas and Data in Statistical Analysis. Bandung: Alfabeta

7. Indriantoro, Supomo N, Bambang (1999) Business Research Methodology for Accounting \& Management. Yogyakarta: BPFE Publisher.

8. Siregar S (2012) Parametric Statistics for Quantitative Research, First Printing Jakarta: PT Bumi Aksara. 